\title{
Nexus Between Macroeconomic Factors and Economic Growth in Palestine: An Autoregressive Distributed Lag Approach
}

\author{
Mosab I. Tabash \\ Al Ain University \\ Umar Farooq ( $\square$ umerrana246@gmail.com ) \\ Xi'an Jiaotong University https://orcid.org/0000-0002-5772-5243 \\ Samir K. Safi \\ United Arab Emirates University \\ Muhammad Nouman Shafiq \\ Xi'an Jiaotong University
}

\section{Research}

Keywords: ARDL, Economic Growth, Macroeconomic Factors, Palestine Economy

Posted Date: February 16th, 2022

DOI: https://doi.org/10.21203/rs.3.rs-1114817/v1

License: (c) (i) This work is licensed under a Creative Commons Attribution 4.0 International License. Read Full License 


\section{Abstract}

All the countries are trying their best to achieve maximum economic prosperity through employing efficient economic strategies. Such countries seem to be conscious of various factors that can potentially affect economic growth. Given that, the current study examines the impact of various macroeconomic factors on the economic growth of Palestine. By employing the large range of quarterly data spanning from 2001 to 2020, the statistical outputs of the ARDL model show that government debt, donations, government expenditures, and unemployment rate adversely impact economic growth. However, other factors including credit facilities, inflation, and total investments positively impinge upon the economic growth of Palestine. Such dynamic impact of various macroeconomic factors displays the detrimental and growth promising role of macroeconomic factors in determining economic prosperity. Our analysis suggests various policy implications to economic policy officials regarding the effectiveness of various factors for economic health. It is further recommended to international agencies working in aid and donations intensive countries to design efficient economic policies that can help such economic in coming out from economic distress.

\section{Introduction}

It is an immense need of the current age to sustain the economic growth in order to ensure the better living standard for residents of the country (Dauda, 2017). For this purpose, the policy officials make some strategies and focus on other economic indicators including trade, investment, borrowings, and inflation, etc., to escalates the economic growth. In this regard, a large number of studies explore different factors affecting economic growth (Mohseni \& Jouzaryan, 2016; Guzman, et al., 2018; Awad \& Karaki, 2019; Jedidia \& Guerbouj, 2021). The empirical outputs of these studies suggest the dynamic association between different macroeconomic factors and economic growth in different economies of the world. However, the emerging literature is silent on quantifying the dynamic effect of such factors on the economic growth of Palestine. Given that, the current study seeks to discover the impact of multiple macroeconomic factors on the economic health of Palestine. This study comprehensively considers the various factors as indicated by previous studies and checks their association in relationship with economic growth of Palestine. Additionally, the current study combines the different strands of literature and present their relationship in a single analysis.

Among the others, some key factors that adhered to economic growth and dominantly determine economic health are debt volume, government expenditures, and government investment, etc., as suggested by prior studies. From a growth perspective, the volume of debt acquired by a country may impede or increase economic growth. In this regard, an empirical study conducted by Spilioti and Vamvoukas (2015) has vowed the positive effect of debt volume on the economic growth of Greek, implying the growth promising role of debt that can be used in renovation or expansion of different development projects. Some other empirical studies have also supported this notion in alternative data specifications (Bal \& Rath, 2014; Ndoricimpa, 2020; Makhoba, et al., 2021). However, some studies have posited the adverse association of debt level with economic status (Daud \& Podivinsky, 2014; Kharusi \& Ada, 2018; Asteriou, et al., 2021), suggesting the hampering role of debt in determining economic growth. Such inconclusive outcomes of literature argue to further arrange the more empirical studies that specify the dynamic influence of macroeconomic factors on the economic growth of a country.

The current empirical analysis tends to find out the dynamic impact of various macroeconomic factors on the growth of real GDP of Palestine. In the current analysis, the volume of GDP is a dependent variable while government debt, total investment, government expenditures, and donations, etc., serve as explanatory variables. For regression analysis, we employ the quarterly data ranging from 2001Q1 to 2020Q4 and apply the Autoregressive Distributed Lag (ARDL) model to quantifies the regression. The statistical findings imply that government debt, donations, government expenditures, and the unemployment rate have a negative impact whilst credit facilities, inflation, and total investment positively and significantly influence the economic growth of Palestine. Such dynamic impact of various macroeconomic factors depicts that government debt enhances the burden of interest payments and negatively impinges upon the real GDP. Similarly, the

Page 2/16 
receipt of donations may hamper the economic health by influencing the institutional efficiency and worsening the efficiency of policy officials due to more dependence on donations. The government expenditures lead to deteriorating the real GDP for unmatured economy owing to fewer amount of funds to cover such expenditures and improper management of funds due to high corruption rate. The negative influence of unemployment can be defined as high unemployment led to low per capita income and thus fewer economic activities.

In contrast, the positive association of credit facilities with real GDP shows the favorable impact of private funds on the exploration of economic activities that further results in positive economic status. Similarly, the positive correlation of the inflation rate with economic growth suggests that the inflation rate may lead to more economic progress as it encourages the producers on voluminous production due to the price appreciation phenomenon. Lastly, the positive interaction of total investment with economic growth exemplifies the significance of government spending in expediating the attached economic activities. The findings of the study add new thoughts regarding the dynamic impact of various economic factors on the real GDP of Palestine. Our analysis provides robustness to empirical findings of existing empirical studies arranged on other economies of the world and suggests focusing on these factors to achieve the objective of better economic status in Palestine. The policy officials should pay more attention to such factors that appeared as hampering the economic growth and should develop some policy modifications to treat such factors. They should further escalate the other factors e.g., private credit facilities, and more investment to sustain the economic growth.

The other parts of the paper address the following sections: Section 2 illustrates the review of previous studies, section 3 describes the material and methods, and section 4 presents the main empirical analysis and section 5 contains the explanation of these results. Lastly, section 6 provides the conclusion and suggests some policy implications. The bibliographical detail of references used in the body of paper has provided at the bottom of paper.

\section{Literature Review}

Economic growth is a multifaceted factor that effecting from other factors including external borrowings, total investment, government spending, donations, and inflation rate, etc. In this regard, a number of studies emerged in the literature that tends to explain the impact of such factors on real GDP, commonly known as economic growth. For instance, Kharusi and Ada, (2018) examined the correlation between external borrowings and the economic growth of Oman. They have found a negative relationship, implying that an increase in external debt can enhance the burden of interest payments which further hampers the economic growth. Supporting this, another study conducted by Abdelaziz, et al., (2019) has specified the channel through which external debt deteriorated the economic growth. They have suggested that a higher volume of external debt impedes investment due to costly financing and hence leads to negative economic growth. Similarly, Razzaque, et al., (2017) have documented the association between exchange rate volatility and economic growth. The empirical analysis of their study indicated that a $10 \%$ decline in the exchange rate may lead to a $3.2 \%$ increase in real output, indicating the favorable impact of a lower rate of exchange on economic expansion. The findings of their study appeal for re-considering the exchange rate policy for Bangladesh to achieve the objective of high economic development. Similar effects were also found by another study arranged by Habib, et al., (2017) on some developing economies. An appreciation in the rate of currency exchange (depreciation in the exchange rate) significantly reduced the real GDP (enhance the real GDP).

The receipt of donations is another factor that can affect the situation of economic prosperity. This effect is more obvious in poor countries or countries bearing the economic status of under-developed or aid intensive (Bayinah, 2017). Donations are made in various forms including gifts, monetary help, or other consumable goods that may enhance human well beings in specific regions (Cappellari, et al., 2011). In Islamic states, mostly donations are made in the form of Zakat. Some studies have attempted to find its association with economic growth. For instance, Jedidia and Guerbouj, (2021) have examined the effect of Zakat inflow on the economic expansion of 8 Islamic states and found robust evidence on favorable impacts of such inflow on real GDP. They have argued that the receipts of such funds can be used to fund the 
investment and other government expenditures that can further augment economic growth. Similarly, another study arranged by Athoillah (2018) has suggested the positive influence of Zakat on economic development while the adverse effect on poverty. However, no specific study found that explore the direct relationship between donations and economic development particularly in Palestine.

Some other studies have apparently considered the availability of credit as an important factor to achieve the economic expansion. ALZYADAT (2021) studied the impact of bank credit facilities on the non-oil economic growth of Saudi Arabia. The empirical analysis of his study reveals that credit facilities have favorable influence on extending the economic activities that eventually lead to positive economic growth. Such credit facilities help in capital formulation and financing development projects. Duican and Pop (2015) evaluated the impact of credit facilities on the economic growth of Romania and found the positive influence of such facilities in expanding the economic activities. Additionally, the inflation rate has a dynamic impact on economic development. Some studies have argued the positive effect (Villavicencio \& Mignon, 2011; Law \& Singh, 2014) while others supported the negative effect of inflation rate on economic activities of an economy (Bick, 2010; Bittencourt, et al., 2015; Khan \& Hanif, 2020). The proponents of the inflation rate have argued a threshold point on which inflation may boost economic growth. Beyond this threshold point, inflation mostly impedes the economic activities due to the inflationary effect of prices on the demand of consumers which turn the consumption rate to the lower end.

It is necessary for each country to spend a significant amount of funds to finance its running operations. Such types of spending have a dynamic association with economic development of this country. Given that, Hamdi and Sbia (2013) have found a vigorous relationship between government expenditures, oil revenues, and economic development in the economy of Kingdom of Bahrain. The empirical analysis of their study suggested that oil revenues are a major source for financing the government spending that may have a negative impact if exceeded from this revenue. They have further conjectured that such spending may impede the economic expansion specifically for oil- dependence economies because such economies are more open to any economic shocks that can enhance the volatility of oil revenue. Another study arranged by Onifade, et al., (2020) have documented the negative impact of expenditures on economic development of Nigeria. Such negative effects of government spending on economic expansion can be supported by the view that spending can create financial stringency for developing countries and thus may reduce the growth of the economy (Ahuja \& Pandit, 2020).

Some other empirical studies further provide the quantitative assessment of the mixed influence of government investment and unemployment on economic development. For instance, Vedia-Jerez and Chasco (2016) estimated the positive effect of domestic investment on the economic growth of South American economies. They have suggested that economic growth was driven by physical investment in capital accumulation by the government. Nguyen and Trinh (2018) have also supported the similar effects for Vietnam and vowed that both public and private investments have positive effects on both short-term and long-term economic growth. Irrespectively, literature has illustrated the detrimental outcomes of unemployment for economic development. Ahuja and Pandit, (2020) have confirmed the negative effect of unemployment on economic expansion in 59 economies from different area of the globe. However, Sadiku, et al., (2015) found robust evidence on the insignificant effect of unemployment on economic growth. Pasara and Garidzirai, (2020) have also suggested the insignificant effect of unemployment on economic progress in the short run. Briefly, the literature argued the dynamic impact of various macroeconomic factors on economic growth for different countries of the globe. In the current analysis, we will test such literature findings for the Palestine case. Additionally, the inconclusive findings of previous studies further urge to arrange more empirical studies on this theme.

\subsection{Path Analyses}

The review of empirical findings of previous studies suggests the following relationship. 
Table 1

Summary of Literature Survey

\begin{tabular}{|lll|}
\hline \multicolumn{3}{|l|}{ Dependent Variable $=$ Read GDP } \\
\hline Sr no. & Variable name & Suggested relationship \\
\hline 1 & Government Debt & Negative \\
\hline 2 & Exchange rate & Positive/negative \\
\hline 3 & Donations & Not specified \\
\hline 4 & Credit facilities & Positive \\
\hline 5 & Inflation rate & Negative/positive \\
\hline 6 & Government expenditures & Negative \\
\hline 7 & Total investment & Positive \\
\hline 8 & Unemployment & Negative \\
\hline Source: literature survey & \\
\hline
\end{tabular}

Table 1 summarized the empirical findings emerged from survey of literature. The suggested relation of a specific variable is purely based upon the literature suggestions.

\section{Material And Methods}

\subsection{Data}

The statistical information of under-analysis variables was collected from Palestinian Monetary Authority Online and the Palestinian Central Bureau of Statistics. In this study, we have used the quarterly data ranging from initial quarter (Q1) of 2001 to last quarter (Q4) of 2020. The quarterly data provide more comprehensive views about economic strategies and their accumulative effects on overall economic health. To better exemplifies the bond between explained and explanatory variables, the following econometric equation was developed.

$G D P_{t}=\beta_{\circ}+\alpha_{1} G D_{t}+\alpha_{2} T I_{t}+\alpha_{3} G E_{t}+\gamma_{1} D N S_{t}+\gamma_{2} C P I_{t}+\gamma_{3} E X G_{t}+\gamma_{4} U N P_{t}+\gamma_{5} C R F_{t}+\epsilon_{t} e q .(1)$

In equation (1), the GDP is for gross domestic product that shows the total value of all items generated from all resources within an economy during a specific period. The GD is an acronym of government debt, illustrating the total volume of internal and external debt. Similarly, GE indicates the government expenditures on development and non-development projects. DNS is for donations and shows the monetary value of all gifts, charities, and other aids that were received to enhance the human development within country. This amount further demonstrates the dependency of a country on foreign donations. The $\mathrm{CPI}$ is an abbreviation of consumer price index which shows the annual growth in the prices of daily consumable goods by retail customers. In current study, we have considered the quarterly span thus this shows the quarterly increment in prices of goods. EXG is exchange rate which shows the conversion rate of Palestine currency comparative to U.S. dollar rate. The unemployment rate is abbreviated as UNP showing the percentage of total labor force that are unable to find a job or are out of work. Lastly, the CRF depicts the credit facilities to finance the business activities. The brief explanation of variables has also been supplied in Table 2. The measurement of these variables has also specified by a stream of previous studies (Abdelaziz, et al., 2019; Onifade, et al., 2020; Farooq, et al., 2021). The subscript $t$ shows the nature of variable i.e., time series, $\beta$ is constant, and $\epsilon_{t}$ is a residual term.

\subsection{Variables}


Table 2

Variables Specifications

\begin{tabular}{|c|c|c|c|}
\hline Variable Name & $\begin{array}{l}\text { Title } \\
\text { role }\end{array}$ & Calculation & Reference \\
\hline $\begin{array}{l}\text { Economic } \\
\text { growth }\end{array}$ & DV & GDP growth rate & $\begin{array}{l}\text { (Awad \& } \\
\text { Karaki, } \\
\text { 2019) }\end{array}$ \\
\hline $\begin{array}{l}\text { Government } \\
\text { Debt }\end{array}$ & IV & Total debt outstanding (external + internal) & $\begin{array}{l}\text { (Kempa \& } \\
\text { Khan, 2016) }\end{array}$ \\
\hline $\begin{array}{l}\text { Total } \\
\text { Investment }\end{array}$ & IV & Total investment is a gross capital formation by the central government & $\begin{array}{l}\text { (Agostino, et } \\
\text { al., 2016) }\end{array}$ \\
\hline $\begin{array}{l}\text { Government } \\
\text { Expenditures }\end{array}$ & IV & $\begin{array}{l}\text { Total amount of expenditures made by federal government into } \\
\text { development and non-development projects }\end{array}$ & $\begin{array}{l}\text { (Agostino, et } \\
\text { al., 2016) }\end{array}$ \\
\hline Donations & IV & $\begin{array}{l}\text { Donations are total amount of funds received in the form of gifts and } \\
\text { charity. It further comprises of total funds received for development of } \\
\text { human-well beings projects. }\end{array}$ & $\begin{array}{l}\text { (Jedidia \& } \\
\text { Guerbouj, } \\
\text { 2021) }\end{array}$ \\
\hline Inflation & IV & Proxied by CPI & $\begin{array}{l}\text { (Mohseni \& } \\
\text { Jouzaryan, } \\
\text { 2016) }\end{array}$ \\
\hline Exchange rate & IV & It shows the average exchange rate of local currency into dollar amount. & $\begin{array}{l}\text { (Guzman, et } \\
\text { al., 2018) }\end{array}$ \\
\hline Unemployment & IV & Percentage of labor force that is not working and jobless. & $\begin{array}{l}\text { (Mohseni \& } \\
\text { Jouzaryan, } \\
\text { 2016) }\end{array}$ \\
\hline $\begin{array}{l}\text { Credit } \\
\text { Facilities }\end{array}$ & IV & $\begin{array}{l}\text { It shows the volume of funds that are available to finance the existing } \\
\text { business activities or to extend the established business entities. }\end{array}$ & $\begin{array}{l}\text { (Samargandi } \\
\text { \& Kutan, } \\
\text { 2016) }\end{array}$ \\
\hline
\end{tabular}

\subsection{Methodology Discussion}

The ARDL (Autoregressive Distributed Lag) co-integration technique or bound co-integration technique was initially proposed by Pesaran, et al., (2001). The implication of this technique has various advantages over other time-series economics techniques. Nkoro and Uko, (2016) stated that, unlike other techniques, the ARDL co-integration technique has not required a pre-test for unit roots. Consequently, this technique is mostly preferred for the co-integrated variables having different order, I (0), I (1) or a combination of both, and robust when underlying variables have a single long-run relationship in a small sample size.

While the long-run relationship among variables has been detected by applying F-statistic (Wald test). Using this approach, the long-run relationship of series is said to occur only when the F-statistics value exceeds the critical value limit. The main advantage of this approach is to identify co-integrating vectors where there are multiple con-integrating vectors. However, this technique is inappropriate in the existence of an integrated stochastic trend of I (2). Testing for unit roots may be appropriate, though not as a necessary condition. Based on forecast and policy stance, it is necessary to determine the conditions for the ARDL co-integration technique to prevent its unfair application and estimation. If the conditions are not met, it will lead the model to inconsistent and unrealistic expectations.

So, the unit root test is applicable to check the stationarity in a time series. This test is before avoiding the presence of spurious regression, as Ouattara (2004) suggests that bound test in ARDL co-integration approach is based upon the 
assumption that the underlying variables are at the order of I(0) or I(1). So, F-statistics provided by Pesaran, et al., (2001) based upon the variables at the order of I (2) provides invalid outcomes. Similarly, various other tests are employed to check serial correlation and heteroscedasticity.

The ARDL co-integration strategy will be used if the variables are discovered to be in the order of I (0) or I (1). There are three essential steps to it: The first stage is to establish the long-run link between the variables by using an error correcting method regression to test for the significance of lagged variables. The error correction mechanism equation will then be created by adding the initial lag of each variable to the equation. An F-test on the significance of all the lagged variables is used to perform a variable addition test. The second step entailed calculating the ARDL form of the equation where the optimal lag length will be determined according to standard criteria such as the Akaike Information or Schwartz Bayesian (Sekaran, 1992). The final step is to calculate the error correction equation utilizing the variables' differences and the lagged long-run solution, as well as the rate of return to equilibrium adjustment.

\section{Results}

\subsection{Descriptive Investigation}

Table 3

Descriptive Analysis

\begin{tabular}{|lllllll|}
\hline & Mean & Median & Std. Dev. & Maximum & Minimum & Obs. \\
\hline GDP (economic growth) & 3.227 & 3.284 & 0.193 & 3.562 & 2.874 & 80 \\
\hline GD (government debt) & 3.393 & 3.337 & 0.149 & 3.629 & 3.146 & 80 \\
\hline TI (Total investment) & 3.441 & 3.514 & 0.165 & 3.615 & 3.095 & 80 \\
\hline GE (government exp.) & 2.933 & 2.905 & 0.171 & 3.296 & 2.547 & 80 \\
\hline DNS (Donations) & 4.027 & 4.049 & 0.138 & 4.199 & 3.751 & 80 \\
\hline CPI (Inflation) & 2.409 & 2.440 & 0.072 & 2.485 & 2.263 & 80 \\
\hline EXG (exchange rate) & 1.070 & 1.050 & 0.044 & 1.167 & 1.003 & 80 \\
\hline UNP (unemployment) & 1.397 & 1.403 & 0.047 & 1.551 & 1.227 & 80 \\
\hline CRF (credit facilities) & 3.485 & 3.479 & 0.132 & 4.003 & 2.974 & 80 \\
\hline \begin{tabular}{l} 
Source: Self-estimation. Description: Mostly values are in logarithmic form and show the relevant trend of specific \\
\hline variables.
\end{tabular} & & & & \\
\hline
\end{tabular}

In Table 3, we have presented the descriptive statistics of variables. Before formal analysis, we check the normality of data. The statistical value of the Histogram Normality test depicts that data are not normal in its original form. Thus, we apply the natural logarithm to make the data normally distributed. In pursuance of this, the values of variables are presented in logarithmic form. Considering the statistics of descriptive analysis, the mean value of GDP is 3.227 with a maximum value of 3.562. These values show the volume of total GDP in Palestine. As the sample comprises quarterly data for 20 years, therefore the numbers of observations are 80 . Among the other statistics, if we focus on statistical values of GDP and government debt, the value of GD is greater than the value of GDP $(3.93>3.227)$ suggesting the less capacity of Palestine economy to pay back its loans. These values further shows that Palestine economy has a high risk of default which further can cause the financial panic both in international and domestic market.

\subsection{Correlation Statistics}


Table 4

Correlation Analysis

\begin{tabular}{|c|c|c|c|c|c|c|c|c|c|}
\hline & GDP & GD & TI & GE & DNS & CPI & EXG & UNP & CRF \\
\hline GDP & 1.000 & & & & & & & & \\
\hline GD & 0.834 & 1.000 & & & & & & & \\
\hline TI & 0.755 & 0.755 & 1.000 & & & & & & \\
\hline GE & 0.124 & -0.216 & 0.302 & 1.000 & & & & & \\
\hline DNS & 0.875 & 0.891 & 0.943 & 0.076 & 1.000 & & & & \\
\hline CPI & 0.776 & 0.820 & 0.860 & 0.198 & 0.772 & 1.000 & & & \\
\hline EXG & -0.869 & -0.671 & -0.883 & -0.280 & -0.835 & -0.846 & 1.000 & & \\
\hline UNP & -0.135 & 0.134 & -0.161 & -0.220 & -0.117 & -0.112 & 0.191 & 1.000 & \\
\hline CRF & 0.849 & 0.941 & 0.877 & -0.101 & 0.871 & 0.923 & -0.795 & -0.026 & 1.000 \\
\hline \multicolumn{10}{|c|}{$\begin{array}{l}\text { Source: Self-estimation. Acronyms: GDP=GDP growth rate, } G D=\text { government debt, } \mathrm{Tl}=\text { total investment, } \mathrm{GE}= \\
\text { government expenditures, } \mathrm{DNS}=\text { donations, } \mathrm{CPI}=\text { inflation, } \mathrm{EXG}=\text { exchange rate, } \mathrm{UNP}=\text { unemployment, } \mathrm{CRF}=\mathrm{credit} \\
\text { facilities }\end{array}$} \\
\hline
\end{tabular}

Table 4 depicts the correlation values among the variables of study. The correlation value of GD is 0.834 , showing the high correlation trend with GDP. Similarly, the correlation values of other variables including TI, DNS, CPI, EXG, and CRF are $0.755,0.875,0.776,-0.869,0.849$ relatively. The higher correlation values show that most variables are highly correlated with each other due to their similar nature (macroeconomic variables). However, GE and UNP have smaller correlation values as 0.124 and -0.135 .

\subsection{Regression Analysis}

The results of the Augmented Dicky Fuller test have presented in Table 5, confirming that all considered variables of study are integrated at order zero or one. As a result, the ARDL Bound test is used here, with no variable integrated at order 2 , which complicates F-statistics. 
Table 5

ADF (Augmented Dickey Fuller (Unit Root)) Test

\begin{tabular}{|c|c|c|c|}
\hline \multirow[t]{3}{*}{ Variable } & Level & First difference & Decision \\
\hline & t-Statistics & t-Statistics & \\
\hline & Prob.* & Prob.* & \\
\hline \multirow[t]{2}{*}{ GDP } & -0.348 & -3.274 & I (1) \\
\hline & 0.911 & $0.019 *$ & \\
\hline \multirow[t]{2}{*}{ Government Debt } & -1.620 & -3.184 & I (1) \\
\hline & 0.467 & $0.024^{\star}$ & \\
\hline \multirow[t]{2}{*}{ Total Investments } & -1.482 & -5.389 & I (1) \\
\hline & 0.537 & $0.000 * *$ & \\
\hline \multirow[t]{2}{*}{ Govt. Expenditures } & -1.941 & -3.580 & I (1) \\
\hline & 0.312 & $0.008 * \star$ & \\
\hline \multirow[t]{2}{*}{ Donations } & -2.128 & -2.108 & I (1) \\
\hline & 0.234 & $0.034^{\star}$ & \\
\hline \multirow[t]{2}{*}{$\mathrm{CPI}$} & -2.906 & -6.192 & I (0) \\
\hline & $0.049 *$ & $0.000 * \star$ & \\
\hline \multirow[t]{2}{*}{ Exchange rate } & -4.080 & -6.498 & $I(0)$ \\
\hline & $0.010 * \star$ & $0.000 * *$ & \\
\hline \multirow[t]{2}{*}{ Unemployment rate } & -4.563 & -7.292 & $\mathrm{I}(0)$ \\
\hline & $0.000 * \star$ & $0.000 * \star$ & \\
\hline \multirow[t]{2}{*}{ Credit facilities } & -3.403 & -3.897 & I (0) \\
\hline & $0.048^{*}$ & $0.016^{\star}$ & \\
\hline
\end{tabular}

The initial stage in ARDL is to establish lag length criteria, and the shortest lags are ideal for time series analysis in order to prevent losing a degree of freedom. The parameters for selecting the lag order are listed in Table 6.

Table 6

VAR Lag Order Selection Criteria (TAX and FDI)

\begin{tabular}{|lll|}
\hline Lag & AIC & SC \\
\hline 0 & -31.162 & -30.890 \\
\hline 1 & -54.080 & -51.361 \\
\hline 2 & $-56.569 *$ & $-51.403^{*}$ \\
\hline \multirow{2}{*}{\begin{tabular}{l} 
*lndicates lag order selected by the criterion, Akaike Information Criterion (AIC) and Schwarz Information Criterion (SC). \\
\hline
\end{tabular}} \\
\hline
\end{tabular}


Table 7 illustrates that the ARDL model's calculated value is 6.027 , which is over the upper bound critical threshold. Thus, rejecting the null hypothesis shows a long-term association.

Table 7

ARDL bounds Testing Analysis

\begin{tabular}{|lll|}
\hline Model Estimated & Model: GDP = f (GD, EXG, DNS, CRF, CPI, GE, TI, UNP) \\
\hline F-Statistics & 6.027 & \\
\hline Selected Lag Length (Criteria) & 2 (AIC) & \\
\hline M. H. Pesaran et al. (2001) & & Upper Bound Value \\
\hline Critical bound values & Lower Bound Value & 3.060 \\
\hline $10 \%$ & 1.950 & 3.390 \\
\hline $5 \%$ & 2.220 & 3.700 \\
\hline $2.5 \%$ & 2.480 & 4.100 \\
\hline $1 \%$ & 2.790 & \\
\hline Source: self-estimation. & & \\
\hline
\end{tabular}

The ARDL model coefficients are shown in the upper half of Table 8. The coefficient of the Error Correction Model, which represents the short-run impact of variables, is provided in the lower section of the table. At a $5 \%$ level of significance, the residual term is statistically significant but have a negative sign. An ECM coefficient, -0.089 , from the table shows that a short-run disequilibrium can be brought to a long-run equilibrium in a year at a rate of almost 9 percent. Additionally, the model fulfills all of the specified diagnostic tests. As a result, analytic tests are included at the conclusion of the table to ensure that the appropriate model selection was made. 
Table 8

ARDL Model Long-run and Short-run Analysis

\begin{tabular}{|c|c|c|c|}
\hline \multirow[t]{3}{*}{ Variables } & \multicolumn{3}{|c|}{ Dependent Variable: Economic Growth (GDP) } \\
\hline & \multicolumn{3}{|c|}{ Long-run Results } \\
\hline & Coefficient & t-Statistic & Prob. Value \\
\hline GD & -0.398 & -1.642 & $0.105^{\star}$ \\
\hline EXG & -0.488 & -1.108 & 0.272 \\
\hline DNS & -1.262 & -2.107 & $0.039 * *$ \\
\hline CRF & 0.369 & 2.092 & $0.040 * \star$ \\
\hline $\mathrm{CPI}$ & 2.714 & 3.543 & $0.000 * \star \star$ \\
\hline GE & -0.323 & -2.019 & $0.048 * \star$ \\
\hline $\mathrm{TI}$ & 0.616 & 1.795 & $0.077^{*}$ \\
\hline UNP & -0.779 & -2.136 & $0.036 * *$ \\
\hline \multicolumn{4}{|c|}{ Short-run Results } \\
\hline ECM & -0.089 & -3.270 & $0.001 * \star \star$ \\
\hline$D(\operatorname{GDP}(-1))$ & 0.616 & 5.561 & $0.000 * \star *$ \\
\hline $\mathrm{D}(\mathrm{GD})$ & -0.035 & -1.868 & $0.066^{*}$ \\
\hline$D(E X G)$ & -0.072 & -1.252 & 0.215 \\
\hline $\mathrm{D}(\mathrm{EXG}(-1))$ & 0.180 & 3.097 & $0.003^{\star * *}$ \\
\hline $\mathrm{D}(\mathrm{DNS})$ & -0.112 & -2.400 & $0.019 * *$ \\
\hline $\mathrm{D}(\mathrm{CRF})$ & 0.033 & 1.908 & $0.061^{*}$ \\
\hline $\mathrm{D}(\mathrm{CPI})$ & -0.059 & -0.301 & 0.764 \\
\hline $\mathrm{D}(\mathrm{GE})$ & -0.150 & -4.505 & $0.000 * * *$ \\
\hline $\mathrm{D}(\mathrm{GE}(-1))$ & 0.107 & 3.053 & $0.003^{\star \star \star}$ \\
\hline $\mathrm{D}(\mathrm{TI})$ & 0.427 & 8.834 & $0.000 * * *$ \\
\hline $\mathrm{D}(\mathrm{TI}(-1))$ & -0.304 & -5.299 & $0.000 * * *$ \\
\hline D(UNP) & -0.009 & -0.469 & 0.640 \\
\hline \multicolumn{4}{|c|}{ Diagnostic Tests } \\
\hline Test & & F-statistic value & Prob. value \\
\hline J-B Normalit & & 3.935 & 0.139 \\
\hline \multicolumn{2}{|c|}{ Breusch-Godfrey Serial: Correlation LM Test } & 0.852 & 0.431 \\
\hline \multicolumn{2}{|c|}{ Heteroskedasticity Test: ARCH } & 1.294 & 0.225 \\
\hline
\end{tabular}


The probability values in Table 8 depict that government debt have an adverse impact on real GDP at $1 \%$ level. This value implies that a one percent rise in government debt can diminishes the economic growth by $39.8 \%$. The coefficient value of donations is -1.262 , suggesting the significant but inverse relationship with economic growth. The coefficient values of credit facilities and $\mathrm{CPI}$ are 0.369 and 2.714 relatively. Both values depict the significant and positive association of both factors with economic development. However, the coefficient values of government expenditures (-0.323) and unemployment rate $(-0.779)$ suggest the negative association with economic growth. Lastly, the coefficient value of total investments is 0.616 , implying the positive and significant contribution of total investments in determining the economic growth of Palestine.

\section{Discussion}

The objective of the current study is to assess the influence of various macroeconomic factors on the economic growth of Palestine. For empirical analysis, we employ the 20 years quarterly data ranging from 2001 to 2020 and estimate the regression through the implication of the ARDL model. The statistical outputs of this model first state that the volume of government debt has an adverse effect on real GDP. This negative effect can be explained as debt heightened the burden of long-term interest payments and thus hampers the growth (Bal \& Rath, 2014). The growing level of government debt diminishes the growth orientation of an economy as it shows that a country is unable to meet its expenditures from its revenues. Supporting this, a recent analysis arranged by Abdelaziz, et al., (2019) has documented the negative relationship between debt volume and economic development of low-income countries. As likely to government debt, the donations have a negative influence on the economic expansion of Palestine. The reliance on donations does not fix the need for fundings and can inhibit the efforts towards escaping from economic distress. More dependency on donations can lead to hinder the efforts make by the government for self-sufficiency and thus create a cycle for low economic growth. No specific study was found which directly explains the effect of donations on economic growth. However, some studies have explained the impact of Zakat on economic growth (Bayinah, 2017; Athoillah, 2018; Jedidia \& Guerbouj, 2021) and vowed the dynamic impacts of donations on the economic status of the recipient country.

Following empirical findings, credit facilities show a positive association with economic growth. The availability of more funds can treat the depressing situation of an economy as it provides the monetary fuels for many economic sectors that were less developed due to lacking monetary sources (ALZYADAT, 2021). Additionally, better credit facilities have an unconditional role in boosting the economic activities that further achieve better economic growth (Awad \& Karaki, 2019). In addition to this, the statistical analysis further depicts that the inflation rate measured with CPI has a favorable effect on economic growth. Unlike common literature findings suggesting the negative effect of inflation on economic progress (Bick, 2010; Aloui, et al., 2018; Mandeya \& Ho, 2021), this positive influence somehow explains the specific role of inflation in determining economic growth. This positive effect can also be comprehended as the high inflation may lead to encourage the industrial sector through future price appreciation and thus can enhance domestic production (Farooq, et al., 2021).

As the analysis shows, government expenditures have a negative influence on the real GDP of Palestine. Contrary to the Keynesian approach in which he had suggested that government expenditures may enhance the employment rate and economic growth through more demand for goods (Abouelfarag \& Qutb, 2021), some studies show that government expenditures may lead to a fiscal deficit (Kiran, 2011; Brady \& Magazzino, 2019). A country having more expenditures than its revenue may suffer from negative economic growth because it urges the policy officials to enhance the tax rates to meet the expenditures that can further impede the growth of various sectors. Such a situation is more explicit in under-developed and aid intensive countries like Palestine that are already suffering from fiscal deficit. The statistical analysis further shows that total investment has a constructive relationship with economic development. This positive contribution of investment can be explained as it adds the new stock of capital which helps in boosting the economic activities (Pasara \& Garidzirai, 2020). Additionally, the investment shifts the overall production system of an economy upward.

Page $12 / 16$ 
Lastly, the current analysis shows that unemployment is negatively linked with economic growth. Both factors simultaneously affect each other i.e., some studies argue the effect of economic growth on unemployment (Peretto, 2011; Boubtane, et al., 2013; Almutairi, 2020) while others tend to measure the effect of unemployment on economic growth (Sadiku, et al., 2015; Pasara \& Garidzirai, 2020). The higher unemployment rate in a country can be led to low per capita income and thus less consumption rate. The fewer consumption behavior further impedes economic activities and thus finally achieves negative economic growth (Ahuja \& Pandit, 2020). Summarizing, our empirical analysis provides robust evidence on the dynamic impact of various economic factors on the real GDP of Palestine.

\section{Conclusion And Strategy Suggestions}

This study tends to explain the liaison between economic growth and other macroeconomic factors including government debt, donations, exchange rate, inflation, credit facilities, investment, and unemployment rate. From a literature perspective, the relationship between economic development and other factors has been discussed widely since from 19th century as each country is trying its best to make itself more prosperous. Given that, the current study aims to explore the dynamic impact of various factors on the economic health of Palestine. To achieve the objective, we employ the 20-year quarterly statistics over the period 2001 to 2020 of under-analysis factors. The empirical relationship between the variables was estimated by employing the Autoregressive Distributed Lag (ARDL) model. The statistical analysis illustrates that government debt, donations, government expenditures, and unemployment rates have negative impacts while credit facilities, inflation, and total investment have positive contributions in determining the economic growth of Palestine. Such specific association of each factor with economic growth indicates both stimulus and the detrimental effect of specific factors on Palestine's economy. The Keynesian thoughts of stimulating the economic growth through government expenditures fail in the case of Palestine economy as the results support opposite opinions.

The current empirical analysis suggests important policy recommendations to economic policy officials. The policy officials should carefully decide about the volume of debt and donations as both factors hamper economic growth. Additionally, it is further recommended that government should be cautious about its expenditures as more expenditures may harm the economic growth. However, focusing on physical capital accumulation through investment and ensuring the availability of more credit facilities can uplift the Palestine economy. The emergence of such policy recommendations is purely based on the statistical results. Our analysis adds new thoughts in the extant literature of economics regarding the dynamic effect of macroeconomic factors on the economic development of Palestine. This study is limited to analyzing only one economy i.e., Palestine. In the future, more studies can be conducted by evolving the other economies have similar arrangements or even have diverse economic state. Such arrangements can provide comparative views about dynamic effects of macroeconomic factors on the economic health.

\section{Declarations}

\section{Availability of Data and Materials}

Data used for empirical analysis were sourced from WDI (world development indicators), The World Bank. This data site is freely accessible. Additionally, we do not use any command for regression analysis that require the special reporting.

\section{Author's information}

Mosab I. Tabash is currently working as MBA Director at the College of Business, Al Ain University, UAE. He holds B.E (Industrial Engineering), MBA, and Ph.D. in Management/Finance. His research interests include monetary policies, corporate governance, financial performance, investment management, risk management, tourism, and another interdisciplinary research as well.

Page $13 / 16$ 
Mr. Umar Farooq is an Ph.D. (applied economics) scholar at school of finance and economics, Xian Jiaotong University, China. He has recently published papers in peer-reviewed journals including the Journal of Cleaner Production, International Journal of Finance and Economics, Energy Policy, Global Business Review, and Cogent Business and Management. He is also working as an active reviewer in a number of peer-reviewed journals. His main research interest includes corporate finance, energy finance, financial economics, and macro-economics.

Samir K. Safi: not applicable

Muhammad Nouman Shafiq: not applicable

\section{Conflicting Interests}

All the authors declare that we have no potential conflicts regarding the conduct of research that may interrupt publication process.

\section{Funding}

We have received no funding or any other financial support for the conduct of research.

\section{Author's contribution}

Professor Mosab I. Tabash supervised this research, and helps in drafting, funding acquisition, and methodology. Mr. Umar Farooq has participated as conceptualization, data curation, writing and preparation of original draft while Samir K. Safi has contributed to conceptualization and writing-up. His contribution is also in methodology and implications. Similarly, Muhammad Nouman Shafiq has performed data curation, helping in revision of final draft and preparation.

\section{Acknowledgements}

Not applicable

\section{References}

1. Abdelaziz H, Rim B, Majdi K (2019) External Debt, Investment, and Economic Growth: A Seemingly Unrelated Regression Model for Low-Income Countries. J Econ Integr 34(4):725-745

2. Abouelfarag HA, Qutb R (2021) Does government expenditure reduce unemployment in Egypt? Journal of Economic and Administrative Sciences 37(3):355-374

3. Agostino Gd, Dunne J, Pieroni L (2016) Government Spending, Corruption and Economic Growth, vol 84. World Development, pp 190-205

4. Ahuja D, Pandit D (2020) Public Expenditure and Economic Growth: Evidence from the Developing Countries. FIIB Business Review 9(3):228-236

5. Almutairi N (2020) The effects of oil price shocks on the macroeconomy: economic growth and unemployment in Saudi Arabia. OPEC Energy Review 44(2):181-204

6. Aloui C, Hkiri B, Hammoudeh S, Shahbaz M (2018) A Multiple and Partial Wavelet Analysis of the Oil Price, Inflation, Exchange Rate, and Economic Growth Nexus in Saudi Arabia. Emerging Markets Finance and Trade 54(4):935-956

7. ALZYADAT JA (2021) Sectoral Banking Credit Facilities and Non-Oil Economic Growth in Saudi Arabia: Application of the Autoregressive Distributed Lag (ARDL). Journal of Asian Finance, Economics and Business 8(2):0809-0820 
8. Asteriou D, Pilbeam K, Pratiwi CE (2021) Public debt and economic growth: panel data evidence for Asian countries. J Econ Financ 45(2):270-287

9. Athoillah MA (2018) The zakat effect on economic growth, unemployment and poverty in the island of java: panel data analysis 2001-2012. Ekspansi 10(2):205-230

10. Awad IM, Karaki MSA (2019) The impact of bank lending on Palestine economic growth: an econometric analysis of time series data. Financial Innovation 5:1-21

11. Bal DP, Rath BN (2014) Public debt and economic growth in India: A reassessment. Econ Anal Policy 44(3):292-300

12. Bayinah AN (2017) Role of zakat as social finance catalyst to Islamic banking and economic growth. International Journal of Zakat 2(2):55-70

13. Bick A (2010) Threshold effects of inflation on economic growth in developing countries. Econ Lett 108(2):126-129

14. Bittencourt M, Eyden RV, Seleteng M (2015) Inflation and Economic Growth: Evidence from the Southern African Development Community. South African Journal of Economics 83(3):411-424

15. Boubtane E, Coulibaly D, Rault C (2013) Immigration, Growth, and Unemployment: Panel VAR Evidence from OECD Countries. LABOUR 27(4):399-420

16. Brady GL, Magazzino C (2019) Government Expenditures and Revenues in Italy in a Long-run Perspective. J Quant Econ 17(2):361-375

17. Cappellari L, Ghinetti P, Turati G (2011) On time and money donations. J Socio-Econ 40(6):853-867

18. Dauda RS (2017) Poverty and Economic Growth in Nigeria: Issues and Policies. Journal of Poverty 21(1):61-79

19. Daud SNM, Podivinsky J (2014) Government debt and economic growth in Malaysia: the role of institutional quality. Appl Econ Lett 21(7):1179-1183

20. Duican ER, Pop A (2015) The implications of credit activity on economic growth in Romania. Procedia Economics and Finance 30:195-201

21. Farooq U, Ahmed J, Khan S (2021) Do the Macroeconomic Factors Influence the Firm's Investment Decisions? A Generalized Method of Moments (GMM) Approach. International Journal of Finance and Economics 26(1):790-801

22. Guzman M, Ocampo JA, Stiglitz JE (2018) Real exchange rate policies for economic development. World Development, Volume 110:51-62

23. Habib MM, Mileva E, Stracca L (2017) The real exchange rate and economic growth: Revisiting the case using external instruments. J Int Money Finance 73(B):386-398

24. Hamdi H, Sbia R (2013) Dynamic relationships between oil revenues, government spending and economic growth in an oil-dependent economy. Economic Modelling, Volume 35:118-125

25. Jedidia KB, Guerbouj K (2021) Effects of zakat on the economic growth in selected Islamic countries: empirical evidence. International Journal of Development Issues 20(1):126-142

26. Kempa B, Khan NS (2016) Government debt and economic growth in the G7 countries: are there any causal linkages? Appl Econ Lett 23(6):440-443

27. Khan M, Hanif W (2020) Institutional quality and the relationship between inflation and economic growth. Empirical Economics 58(2):627-649

28. Kharusi SA, Ada MS (2018) External Debt and Economic Growth: The Case of Emerging Economy. J Econ Integr 33(1):1141-1157

29. Kiran B (2011) Sustainability of the fiscal deficit in Turkey: evidence from cointegration and multicointegration tests. International Journal of Sustainable Economy 3(1):63-76

30. Law SH, Singh N (2014) Does too much finance harm economic growth? J Banking Finance 41:36-44

31. Makhoba BP, Kaseeram I, Greyling L (2021) Investigating asymmetric effects of public debt on economic growth in South Africa: a smooth transition regression (STAR) approach. African Journal of Economic and Management Studies 
12(3):486-498

32. Mandeya SMT, Ho S-Y (2021) Inflation, inflation uncertainty and the economic growth nexus: An impact study of South Africa, vol 8. MethodsX

33. Mohseni M, Jouzaryan F (2016) Examining the Effects of Inflation and Unemployment on Economic Growth in Iran (1996-2012). Procedia Economics and Finance 36:381-389

34. Ndoricimpa A (2020) Threshold effects of public debt on economic growth in Africa: a new evidence. Journal of Economics and Development 22(2):187-207

35. Nguyen CT, Trinh LT (2018) The impacts of public investment on private investment and economic growth: Evidence from Vietnam. Journal of Asian Business and Economic Studies 25(1):15-32

36. Nkoro E, Uko AK (2016) Autoregressive Distributed Lag (ARDL) cointegration technique: application and interpretation. Journal of Statistical and Econometric Methods 5(4):63-91

37. Onifade ST et al (2020) An empirical retrospect of the impacts of government expenditures on economic growth: new evidence from the Nigerian economy. Journal of Economic Structures, Volume 9

38. Ouattara B (2004) Modelling the Long Run Determinants of Private Investment in Senegal. Economics Discussion Paper Series 0413

39. Pasara MT, Garidzirai R (2020) Causality Effects among Gross Capital Formation, Unemployment and Economic Growth in South Africa. economies, 8(2), pp. 1-12

40. Peretto PF (2011) Chapter 19 Market Power, Growth, and Unemployment. de La Grandville, O. (Ed.) ed. Bingley: Emerald Group Publishing Limited

41. Pesaran HH, Shin Y, Smith RJ (2001) Bounds testing approaches to the analysis of level relationships. J Appl Econom 16(3):289-326

42. Razzaque MA, Bidisha SH, Khondker BH (2017) Exchange Rate and Economic Growth: An Empirical Assessment for Bangladesh. Journal of South Asian Development 12(1):42-64

43. Sadiku M, Ibraimi A, Sadiku L (2015) Econometric Estimation of the Relationship between Unemployment Rate and Economic Growth of FYR of Macedonia. Procedia Economics and Finance 19:69-81

44. Samargandi N, Kutan AM (2016) Private credit spillovers and economic growth: Evidence from BRICS countries. J Int Financ Mark Inst Money 44:56-84

45. Sekaran U (1992) Research Methods For Business: A Skill Building Approach. Second Edition ed. New York: John Wiley \& Sons

46. Spilioti S, Vamvoukas G (2015) The impact of government debt on economic growth: An empirical investigation of the Greek market. The Journal of Economic Asymmetries 12(1):34-40

47. Vedia-Jerez DV, Chasco C (2016) Long-Run Determinants of Economic Growth in South America. J Appl Econ 19(1):169-192

48. Villavicencio AL, Mignon V (2011) On the impact of inflation on output growth: Does the level of inflation matter? J Macroecon 33(3):455-464 